\title{
Japanese New Patent Law: Lessons for China
}

\section{Meirong Guo}

Department of Social Engineering, Graduate School of Decision Science and Technology, Tokyo Institute of Technology, Tokyo, Japan. Email: guo_mei_rong@hotmail.com

Received June $27^{\text {th }}, 2012$; revised July $29^{\text {th }}$, accepted August $10^{\text {th }}, 2012$

\begin{abstract}
In this paper, I systematically analyze the new Japanese Patent Law and make a comparative study on Chinese and Japanese Patent Law to shed a new light on the improvement of the legal system of intellectual property in China. To begin with, I review the historical development of Japanese Patent Law and the modern patent legal system in Japan. Next, the aim and contents of the latest revision of Japanese Patent Law are described. I also pay close attention to the issues remaining unresolved. Regarding the problems faced by Chinese Patent Law, I identify the lessons that China could learn from Japanese New Patent Law. Finally, I suggest that there are still some unresolved issues in Chinese Patent Law even after learning from the new Japanese Patent Law.
\end{abstract}

Keywords: Japanese Patent Law; Chinese Patent Law; Comparative Study

\section{Introduction}

Globalization has proceeded at an unprecedented pace in the late twentieth and twenty-first centuries. The advent of an international economic order has fundamentally changed the nature of the global economy, affecting governments as well as firms and individuals in every nation and region [1]. The development of global economy could be promoted by an effective system of intellectual property, which plays significant role in encouraging innovation, product development and technical change. The patent law in the intellectual property right (IPR) system is closely related to domestic industrial development and external economic competitiveness.

China has made great achievements in its economic development since it became a member of World Trade Organization (WTO) in 2001 [2]. The overall economic scale of China is keeping up with that of developed countries. However, the legal system of intellectual property in China has fallen behind the industrialization with continuous high-speed growth. Specifically, Chinese Patent Law is quite behind the counterparts in developed countries. For instance, Japan is known to have greatly benefited from intellectual property generated in other developed countries. In Japan, the patent protection has been designed for the ultimate objective of industrial development [3]. It has several features that have helped the absorption of spillovers of foreign inventive activity by domestic enterprises. As we all know, Japan is an important trading partner of China. Therefore, it would be beneficial for China to have a clear understanding of
Japanese Patent Law in order to improve its legal system of intellectual property with respects of the rapid economic growth between China and Japan. It is also crucial to pay attention to the development of Japanese Patent Law because it has been revised frequently. There are a lot of differences between Chinese Patent Law and the Japanese one. For instance, there are three kinds of protection (patent for invention, utility model, and design) in Chinese Patent Law, whereas a patent refers to only an invention in Japanese Patent Law. The protections of utility model and design are the task of Utility Model Act and Design Act, respectively.

The present Chinese Patent Law was enacted in 1984. There are still some unresolved issues in Chinese Patent Law, although it has been improved through frequent revisions, most recently in 2008 [4]. For example, some provisions were not involved in Chinese Patent Law, such as the legal protection of inventors in joint research, the rule intended to remedy infringed patent rights. In contrast, Japan often revises the Patent Law to meet the needs of industrial development. The latest version of Japanese Patent Law was revised in 2011, which gives some lessons to China, as I argue below. Notwithstanding its significant implications on the possibilities of Chinese Patent Law few efforts have been made in China to analyze and assess the new Japanese Patent Law.

In this paper, I try to systematically analyze the new Japanese Patent Law and to make a comparative study on Chinese and Japanese Patent Law to shed a new light on the improvement of the legal system of intellectual property in China. To begin with, I review the historical 
development of Japanese Patent Law and the modern patent legal system in Japan. Next, the aim and contents of the latest revision of Japanese Patent Law is described. In this description, I pay close attention to the issues remaining unresolved. Regarding the problems faced by Chinese Patent Law, I identify the lessons that China could learn from Japanese New Patent Law. Finally, I suggest that there are still some unresolved issues in Chinese Patent Law even after learning from the new Japanese Patent Law.

\section{The Historical Development of Japanese Patent Law}

I begin with overviewing the historical development of Japanese Patent Law to understand the background of the latest revision of Japanese Patent Law. The purpose of Japanese Patent Law is to meet the needs of industrial development. The law is formulated in order to systematically protect the rights of inventors and promote industry development by means of inventions. The patent system is one of policies intended for the development of industries. The patent law could be a well-balanced legislation to implement such a policy.

In order to promote industry development, Yukichi Fukuzawa introduced the patent system of European and American to Japan for the first time in Meiji era. By his advocacy, Japanese society began to introduce and expand the western patent system. Eventually, Japanese government decided that the patent legal system should be implemented in Japan as soon as possible. As the first Patent Law in Japan, the Rule of Monopoly was promulgated in 1871, although it was abolished one year later without being enforced. Until then, advanced patent ideas had been introduced into Japanese society [5]. Thus, it laid the foundation of the patent system in Japan. The patent system of Japan, Patent Monopoly Act, was enacted in 1885. It was revised as Patent Act in 1888 and the patent system was still continuous. The Japanese government officially renamed "Patent Act" as "Patent Law" in 1899. Up to now, the term of "Patent Law" is still be used. Later, after many revisions made in 1909, 1921 and later at many times, the modern patent system of Japan was fully established [6].

Japanese patent law was established on the basis of domestic law of related areas and was incompatible with the rapidly developing international patent system. In 1959, the Japanese government thoroughly revised the patent law, referring to a large number of legislations in Western countries. In this sense, the present Japanese Patent Law admittedly began from the patent law in 1959. After the fresh start, Japanese Patent Law has been greatly developed.

The current Japanese Patent Law is still based on the patent law in 1959. Since 1989, the major revisions were made in 1994, 1996, 1998, 1999, 2002, 2003, 2004, 2006, 2007, 2008 and 2011. The latest revision of Japanese Patent Law in 2011 will be described at length in the next section [7].

\section{The Latest Revision of Japanese Patent Law}

In recent years, with the development of innovation, an increasing number of companies in Japan have taken full advantage of the technologies outside their own and applied them into research and development (R\&D) in order to realize the commercialization of new products [8]. Accompanied by the above changes, Japanese Patent Law was revised on June 8, 2011 to protect the inventors in joint research and strengthen the protection of license agreement. For the purpose of broadening the range of innovation and solving intellectual property disputes quickly and efficiently, it is thought to be essential to improve the convenience of users by revising trial system [9].

The major changes involved in the new Japanese Patent Law are as follows. First, the new Japanese Patent Law stipulates that a non-exclusive license shall have effect on the person who subsequently acquires the patentee or the exclusive licensee, or the exclusive license on the patent right even if it is not registered. Before the law was revised, a non-exclusive license did not have any effect on any person unless it was registered [10]. There were only a small number of cases in which non-exclusive license was registered because of the high cost and complex procedures of registration. Since there is a potential risk for a holder of non-exclusive registered right to work holder of non-exclusive registered right to work to exercise the rights of a patent from the patentee, the registration system of non-exclusive license was concealed. Suppose that A is the holder of patent, and S the license holder of the patent. Further suppose that A transfers the patent to B (a new holder of the patent) when there is the license agreement between A and S. In this situation, the transfer of the non-exclusive license from A to $S$ shall have effect even if it is not registered when $B$ wants to seek injunction against $S$.

Second, the new Japanese Patent Law provides that the person having the right to obtain a patent (the true holder of the patent right) can apply for the transfer of the rights of a patent in the following two cases. The first is the situation in which the patent is obtained by some of coinventors in a joint research or a joint development; in this case, the objective of the revision is to strengthen the protection of the real inventors of a patent. The second case is that the application of a patent is applied by someone, who is not inventor (usurped application) or who disobeys the rule of joint application (breach of joint application). Before the law was revised, in the cases of 
usurped application and breach of joint application, the true inventor was able to request a trial for invalidation but unable to request the return of the rights in explicit terms. Let us A be an inventor, B neither an inventor nor someone who has the right to obtain a patent and $\mathrm{S}$ a third party. B applies a patent and becomes the holder of the patent when A does not know. $\mathrm{S}$ files a request for a trial for patent invalidation because $B$ is not the true holder of patent right. According to the new law, A has the right to transfer the patent from $\mathrm{B}$ to others. However, before the law was revised, A had the right of litigating a trial for invalidation but was not entitled to the patent right.

Third, there are two revisions in the new Japanese Patent Law for the purpose of improving the convenience of users. The law improves their conveniences by extending the period of reducing or discharging of patent fee. While this period varied from one to three years before the law was revised, the period is from one to ten years after the revision. Moreover, the users are benefited from the new law that broadens the objects applied to the exceptions for lack of novelty. Before the law was revised, these were considered as the case in which the novelty of invention has lost (e.g., the explanation for funding research and development to investors, or an oral presentation at a seminar on research and development consortium). The new Japanese Patent Law revised the provision that objects applied to the exceptions for lack of novelty from the viewpoint of the diversity of means for the laying open of patent application. For example, when the inventor presented his work in an academic conference, the inventor can apply for the patent and the invention would not be regarded as losing the novelty no matter how the inventor made public his work.

Finally, to resolve the disputes quickly and efficiently, the new Japanese Patent Law prohibits the request for a trial for correction after the litigation rescinding the trial decision. In the case of a trial for invalidation, if the prior notice of an appeal is given and the corresponding procedures to request correction are implemented, it is impossible to request a trial for correction after the litigation rescinding the trial decision. The reason for this revision is to resolve the "Catch-ball Effect" and to prevent extensions and useless deliberations. The "Catch-ball Effect" is a term that describes how a case can go back and forth from the Japan Patent Office (JPO) to court, such as the procedure from Trial for Invalidation (JPO), Suit against Appeal Trial Decision (Court) to Correction Trial, then return to Trial for Invalidation (JPO), Suit against Appeal Trial Decision (Court). Thus, after the revision, the system begins from "Trial for Invalidation (JPO) to Suit against Appeal Trial Decision (Court) and returns to Trial for Invalidation (JPO)". All ends at the "Trial for Invalidation (JPO)" [11].

\section{Lessons for Chinese Patent Law}

After joining the World Trade Organization (WTO) in 2001, China has strengthened its legal framework and amended its IPR and related laws and regulations to comply with the WTO Agreement on Trade-Related Aspect of Intellectual Property Rights (TRIPs). Chinese Patent Law was enacted in 1984 and revised in 1992, 2000 and 2008. The aim of the third revision in 2008 was to improve the quality of patents, the protection of national and local public interests, and the balance between patent protection and these public interests. Patents are considered as a measure of technology prowess and innovation. Moreover, patent filing is considered as an indicator of technology innovation in the country. By 2011, the number of new patent applications in China had surpassed those of the United States and Japan so that China is now in a leading position in patent filing all over the world. Although Chinese Patent Law has played primary role in increasing the number of patent filing, such criticisms are often raised that the quality of Chinese patent is not high and that most of patent fillings are applications for utility model and design but not for invention.

Only when Chinese Patent Law continues to be improved, can the goal of building the so-called innovation country be achieved. Chinese Patent Law is very similar to European and U.S. counterparts, with a few exceptions. One of the problems that China is facing now is how to enforce and implement its patent law and policy effectively. Besides, there are three problems that may still exist in Chinese Patent Law. The first problem concerns service invention, which means inventions by employees. Three issues are of great importance and significance. First, how should we define the right of an inventor? Second, how can we accurately distinguish a service invention and a non-service invention? Third, how should the right of a patent be transferred? Moreover, there are still some questions unresolved by the current Chinese Patent Law. For example, who is the patent applicant of service invention? How pay incentive compensation to an inventor?

The second problem is about the system of patent agent. A patent agency, as a professional service agent in the patent system, plays a key role in providing a pre-legal inventor with statutory rights. For the goal of innovation country, the new Chinese Patent Law should protect both the interest of the invention and that of the patent agency. Since China currently makes use of the market economy, it is essential to build a sound system of patent agency consistent with international conventions by revising Chinese patent law. Particularly, the market access of patent agent and the acknowledgement of patent attorney as a market agent should be clarified in 
the patent law in order to enhance the predictability of actions that is essential for the development of free market economy.

The third problem is about administrative and judicial "double protection". Currently, there are two primary ways to resolve patent disputes in China: the administrative route and the judicial one. Because the infringements of patent right are judged in the administrative and judicial processes independently, the resources of government are wasted. In addition, civil disputes in other areas than intellectual property are also decided in some of intellectual property courts. On the other hand, the cases of the infringements of patent right are trialed by the local patent administrative agencies; some of these administrative issues are resorted to administrative pleading proceedings again and thus overburden the government. Although the new Chinese Patent Law has added new articles to improve the current situation, the problem is not yet resolved.

The new Chinese Patent Law was revised in 2008, while the new Japanese Patent Law in 2011. There is a common objective to revise the patent law between China and Japan, which is to improve social innovation. The new Japanese Patent Law established the system of transfer request to adequately protect the inventor in joint research or joint development. As noted above, the problem of service invention is not yet resolved in the current Chinese Patent Law. Regarding the problem of the transfer of patent right, the system of transfer request in the new Japanese Patent Law can be a reference for China. Moreover, the new Japanese Patent Law revised the article that has enlarged the years of reducing patent fee for small company to reduce the burden on business and to encourage more enterprises to apply patents. These new devices give us some insights on how to supply more convenience for users.

\section{Conclusion}

The new Japanese Patent Law was promulgated in June 2011 and will be enforced in April 2012. As I described before, the related articles were amended to strengthen the protection of license contracts and the real inventor (or patent right holder), to improve fairness of dispute resolution and to forbid the request for a trial for correction after the litigation rescinding the trial decision. These will work together for the three goals: meeting the aims to open innovation, making dispute resolution faster and fairer and improving users' convenience. However, there are still some issues unresolved by the new Japanese Patent Law. First, the revision indeed made it possible to oppose the third party, even without the registration with the JPO. However, it does not limit the right of injunction. Thus, there should be different stipulations intended for different industrial areas. Second, the right of transfer is valid in a usurped application, regardless of whether the applicant is a true inventor. Generally speaking, the patentee who obtains a patent right should meet two conditions of invention and patent filing. Therefore, the revision should make it clear whether the applicant is the true inventor. In contrast, in Chinese Patent law, the non-exclusive license holder must register with the Patent Office in order to oppose a third party. Thus, the situation in China is the similar to the situation in Japan before the law was revised. Moreover, in Chinese Patent Law, it is still not possible to return the rights to the true inventor. Therefore, inventors must be cautious of usurped applications and breaches of joint applications. It follows from these all that we can learn valuable lessons from the new Japanese Patent Law.

\section{REFERENCES}

[1] L. Y. Yueh, "Global Intellectual Property Rights and Economic Growth,” Northwestern Journal of Technology and Intellectual Property, Vol. 5, No. 3, 2007, pp. 437-448.

[2] L. F. Wang and H. Wang, "The Protection of Chinese Enterprises' Intellectual Property Rights in the Globalization,” Science Technology and Law, Vol. 8, No. 4, 2008, pp. 40-42.

[3] K. E. Maskus and C. McDaniel, "Impacts of the Japanese Patent System on Productivity Growth," Japan and the World Economy, Vol. 11, No. 4, 1999, pp. 557-574.

[4] D. M. Liu, "The Transplant Effect of the Chinese Patent Law," Chinese Journal of International Law, Vol. 5, No. 3, 2006, pp. 733-752. doi:10.1093/chinesejil/jml035

[5] Y. Du, “The Latest Revising of Japanese Patent Law," Journal of Guizhou Police Officer Vocational College, Vol. 14, No. 4, 2002, pp. 24-27.

[6] A. Muto, "Intelligence Activity and Innovation in Intellectual Property Strategy,” Journal of Information Processing and Management, Vol. 45, No. 7, 2002, pp. 457465. doi:10.1241/johokanri.45.457

[7] M. Kotabe, "A Comparative Study of U.S. and Japanese Patent Systems,” Journal of International Business Studies, Vol. 23, No. 1, 1992, pp. 147-168.

[8] Y. Miyata, "An Economic Analysis of Cooperative R\&D in Japan,” Japan and the World Economy, Vol. 7, No. 3, 1995, pp. 329-345. doi:10.1016/0922-1425(94)00043-S

[9] Minister of Economy, Trade and Industry, "Proposal for the Act to Amend the Patent Act,” 2011. http://www.meti.go.jp/press/20110311005/20110311005. html

[10] Industrial Property Rights System Reform Deliberation Room Editing Patent Office, "Remarks of the Partial Revision of the Law of Industrial Property Rights (as a Part of the Patent Law), FY2011,” Japan Institute of Invention and Innovation, Tokyo, 2011.

[11] F. L. Yu, "Unresolved Problems in the New Chinese Patent Law," The Quarterly Review of Corporation Law and Society, Vol. 6, No. 1, 2009, pp. 82-85. 